\title{
The Efficiency of the Logistics Supply Automotive Company
}

\author{
Sergey V. Noskov ${ }^{1}$
}

\author{
Lilyana A. Sosunova1 \\ 1. Samara State University of Economics, Russia, 443090, Samara, Sovetskoi Armii Street, 141 \\ Correspondence: Samara State University of Economics, 443090, Russia, Samara \\ Sovetskoi Armii Street, 141, Email: noskov50@yandex.ru
}

\section{Doi:10.5901/mjss.2015.v6n6s3p463}

\begin{abstract}
The purpose of the paper is assessment of costs and supply logistics efficiency of JSC AvtoVAZ. Being a part of logistics costs transportation and procurement expenses of the automobile company, expenses connected with production supplies maintenance, administrative expenses are allocated and calculated. The assessment of a costs share of logistics supply in revenue is given. The economic-mathematical method of the automobile company supply logistics efficiency assessment on the basis of integrated indicator calculation is used. The single-unit supply logistics efficiency indicators corresponding to a logistics development level of the domestic automotive industry are allocated. The calculation of JSC AvtoVAZ integrated supply logistics efficiency indicator from 2009 to 2014 is carried out.
\end{abstract}

Keywords: supply logistics, expenses, efficiency, automobile company, integrated indicator, single-unit indicators, correlation coefficient, dispersion, weighting coefficient.

\section{Introduction}

The logistics costs determination and supply logistics efficiency of automotive industry of the Russian Federation are important procedures of logistics management. The purpose of logistics management consists of financial and economic operating indicators enhancement and investment activities of automobile companies, their competitiveness increase under the conditions of the national economy recession and in consumers' demand decrease.

In logistics of purchases and supply of the automobile companies the principles of coordination, integration and optimization of interaction with suppliers of accessories and services, and as well as optimum logistic decision-taking methods are widely used. However logistic expenses management and supply logistics efficiency determination are still an urgent problem of logistic management in terms of the used calculation methods and their assessment reliability.

According to the 25th annual report data on logistics by the Council of Supply Chain Management Professionals (CSCMP), the cost of business and logistic expenses in the USA economy grew to $\$ 1390$ billion in 2013, the cost of stocks increased by $2.8 \%$ in 2013 in comparison with 2012, warehousing expenses - by $3.6 \%$, transport costs - by $2.0 \%$ (25th Annual State of Logistics, 2014). In general, the general logistic expenses made up $8,3 \%$ of the USA GDP of in 2013 that is lower than their level of 2012.

The Council of Supply Chain Management Professionals and the World Bank do the research on the state and conditions of the world and national logistic systems, count logistic costs and its efficiency indicators. But the used methods of logistic expenses definition concern macroeconomic level though the external macro-logistic environment of the certain countries is formed on the basis of the close integration interaction meso and micro logistic subsystems of regions, the markets, clusters, separate companies. Boston Consulting Group and Committee on Logistics of Chamber of Commerce and Industry of the Russian Federation in 2014 conducted surveys of the domestic and foreign companies, manufacturers and logistic services suppliers, logistics specialists, and also consumers on the state and trends of logistics development, its efficiency (Boston Consulting Group and Committee on logistics of Chamber of Commerce and Industry of the Russian Federation, 2014). Among more than 120 Russian and foreign respondents only $34 \%$ estimated logistics costs of the companies equal to $10 \%$ of the output price, $26 \%$ of the respondents - not less than $30 \%$. According to the respondents the greatest share of logistics costs is the share of transport costs (81\%). The wide rating spread of respondents' estimates of the size of logistic expenses by producers and consumers their share in the company revenue requires an assessment of costs of internal logistics and determination of their efficiency. 


\section{Method}

At each investigation phase of company supply logistics efficiency the statistical, mathematic-statistical methods and models corresponding to the done tasks were used.

\subsection{Research Structure}

The research structure consisted of assessment stages of logistic costs of purchases and supply of the automobile company, definition of their share in revenue, the analysis of structure and calculation of a macroeconomic indicators of logistics efficiency, the integrated indicator calculation of supply logistics efficiency of the automobile company from 2009 to 2014.

\subsection{Representativeness of research target}

The choice of JSC AvtoVAZ automobile company as the research target is explained to be a market leader by its sales in the general sales of cars in the Russian market (17.4\%), and also existence of the general organizational and economic conditions of contractor interaction in supply chains of materials and parts.

\subsection{Methods for obtaining and assessing intermediate and final research results}

The transport and procuring expenses were calculated according to the annual reports of JSC AvtoVAZ, the sum of production stocks storage expenses were calculated by direct reference of separate elements of warehousing expenses (without the warehouse and hoisting-and-transport equipment depreciation) to an indicator of storage expenses. Management expenses on supply logistics and fiscal charges were calculated in proportion to a share of fixed assets of warehouse function and current assets in production stocks.

The general costs of JSC AvtoVAZ supply logistics are the sum of operating costs and non-recurring investment in the fixed and working capital. As the current expenses and non-recurring investment make different economic sense and measurement units, the last ones are brought to current and annual dimension on the basis of their profitability indicators in alternative options of their use. Fixed assets of warehouse function and current assets in production stocks can be brought to the current costs of supply logistics, in particular, on the basis of Renault Nissan company assets profitability equal to $5,2 \%$ / per year $(0,052 /$ per year).

The dynamics, structure and interrelations of supply logistics indicators of the automobile company, its expenses share in revenue were calculated.

The mathematic-statistical methods of the research (Pearson correlation coefficients, dispersion) and, as well, as graphic and computer modeling were used.

\section{Results}

The target of the analysis and assessment of supply logistics costs is one of the leading domestic companies in the automobile market of the Russian Federation - JSC AvtoVAZ. Nowadays the carmaker is facing the problems of low business and consumer activity, external borrowings, an increase in prices for foreign components, an unstable financial position of domestic suppliers for material resources, low labor productivity and low competitiveness. Under the created adverse conditions of the external and internal environment of the company its management carries out search for strategic decisions in the sphere of logistics for decreasing expenses on supply chain management (Makarova, 2010).

The methods of logistic costs assessment for purchases and supply existing in scientific and methodical literature are based on allocation of such groups of expenses, as transport and procuring expenses in material inputs, expenses according to the maintenance of production stocks, management expenses, or such groups of expenses as material inputs, capital expenditure and management expenses (Szydelko, 2013). In the other studies costs for purchasing logistics include expenses on operational planning and material resources delivery scheme, product shipping arrangement, costs for customs registration and forwarding, expenses on receiving goods and control of material assets, costs for warehousing and inventory control, supplies inventory financing, expenses on claims management and product refunds (Krajnc et al., 2012). Sometimes as a part of logistic expenses company transactional expenses that arise before making a contract with suppliers are allocated (Mishchersky, 2011). There are studies about differentiation of expenses on logistic operations of product delivery of separate commodity positions as well (Belov, 2001). The features of 
construction logistic expenses structure are considered by D.B.Lytvyna (Lytvyna, 2012), and classifications of logistic expenses in retail- by O. S.Glinskaya and I.S. Skorikovoy (Glinskaya, Skorikova, 2011).

The total amount calculation of the costs for supply logistics including the capital expenditure of JSC AvtoVAZ operating costs and capital input brought to annual dimension for 2009-2014 is presented in table 1.

Table 1. JSC AvtoVAZ total amount calculation of the costs for supply logistics.

\begin{tabular}{|l|c|c|c|c|c|c|}
\hline Показатели & 2009 & 2010 & 2011 & 2012 & 2013 & 2014 (grade) \\
\hline Shipping and handling expenses, RUB bn. per year & 0,62 & 1,01 & 1,24 & 1,31 & 1,94 & 1,27 \\
\hline Storage expenses (except for depreciation), RUB bn. per year & 1,09 & 1,03 & 1,16 & 1,18 & 1,26 & 1,19 \\
\hline Management expenses on inbound logistics, RUB bn. per year & 1,14 & 1,02 & 1,66 & 1,56 & 1,69 & 1,57 \\
\hline Taxes, RUB bn. per year & 0,14 & 0,12 & 0,13 & 0,24 & 0,23 & 0,20 \\
\hline Warehousing capital assets brought to annual dimension, RUB bn. per year & 0,09 & 0,09 & 0,09 & 0,10 & 0,10 & 0,11 \\
\hline Current assets in production supplies brought to annual dimension, RUB bn. per year & 0,54 & 0,49 & 0,57 & 0,60 & 0,65 & 0,59 \\
\hline Total input, RUB bn. per year & 3,62 & 3,76 & 4,85 & 4,99 & 5,87 & 4,93 \\
\hline
\end{tabular}

The most considerable changes of the company supply logistics costs structure in 2014 compared with 2009:

- growth for specific weight of shipping and handling expenses from 17,1 to $25,8 \%$ which is caused by increase in delivery frequency of material resources and, as a result, production stocks turnover acceleration from 5,0 to 11,2 turnovers per year;

- decrease in specific weight of production stocks storage expenses from 30,1 to $24,1 \%$ due to modernization of the warehousing and hoisting-and-transport equipment, improvement of labor organization of warehouse workers and increase of labor productivity.

The indicators of the company supply logistics costs have close dynamic interrelations. So, the gain of average annual cost for production stocks on average by $2,5 \%$ a year caused the gain of warehouse capital assets on average by $3,2 \%$ a year, the gain of production stocks storage costs by $2,0 \%$ a year and management expenses on inbound logistics - by $9,4 \%$ a year.

The methods of a logistics efficiency assessment are developed, first of all, for macroeconomic level. So, according to the research of the World bank, the Russian Federation takes the 90th place in a rating of the countries according to the logistics efficiency index in 2014, and according to the share of logistic expenses in GDP (about 20\%) is above Brazil and India (The World Bank. Logistics Performance Index, 2014).

The logistics efficiency index is an interactive benchmarking tool created for the state problem identification and opportunities in the sphere of trade logistics and increase of its efficiency. The logistics efficiency indicator allows carrying out comparison between 160 countries which are based on the world poll of operators (global forwarding agents and express transport operators) about a condition of the surrounding logistic environment in those countries where they work as well as they trade with. The operators' feedback is supplemented with quantitative data on key components performance of a logistic chain in the country of their activity.

The logistics efficiency indicator consists of quality and quantitative indicators and helps build profiles of logistic loyalty for each one of 160 countries according to six indicators which were chosen on the basis of the recent theoretical and empirical research and practical experience of the professionals in logistics who are in international freight transportation. They are:

1. Efficiency of registration process (speed, simplicity and predictability of formalities) in border control organizations, including customs.

2. Quality of trade and transport infrastructure (ports, railroads, highways, terminals, information technologies).

3. International transportation.

4. Competence and quality of logistic services of transport operators, customs brokers.

5. Possibility of tracking and control of freights.

6. Timeliness of cargo delivery to the destination during the planned or expected delivery time.

The logistics efficiency indicator of the certain countries and its components in 2014 are presented in table 2. 
Table 2. Logistics efficiency indicator and its components

\begin{tabular}{|c|c|c|c|c|c|c|c|c|}
\hline 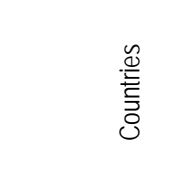 & 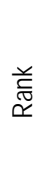 &  & 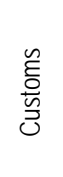 & 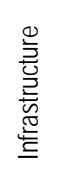 & 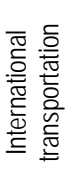 & 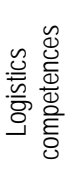 & 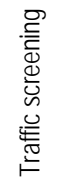 & 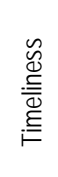 \\
\hline Germany & 1 & 4,12 & 4,10 & 4,32 & 3,74 & 4,12 & 4,17 & 4,36 \\
\hline Netherlands & 2 & 4,05 & 3,96 & 4,23 & 3,64 & 4,13 & 4,07 & 4,34 \\
\hline Belgium & 3 & 4,04 & 3,80 & 4,10 & 3,80 & 4,11 & 4,11 & 4,39 \\
\hline UK & 4 & 4,01 & 3,94 & 4,16 & 3,63 & 4,03 & 4,08 & 4,33 \\
\hline Singapore & 5 & 4,00 & 4,01 & 4,28 & 3,70 & 3,97 & 3,90 & 4,25 \\
\hline Sweden & 6 & 3,96 & 3,75 & 4,09 & 3,76 & 3,98 & 3,97 & 4,26 \\
\hline Norway & 7 & 3,96 & 4,21 & 4,19 & 3,42 & 4,19 & 3,50 & 4,36 \\
\hline Luxemburg & 8 & 3,95 & 3,82 & 3,91 & 3,82 & 3,78 & 3,68 & 4,71 \\
\hline USA & 9 & 3,92 & 3,73 & 4,18 & 3,45 & 3,97 & 4,14 & 4,14 \\
\hline Japan & 10 & 3,91 & 3,78 & 4,16 & 3,52 & 3,93 & 3,95 & 4,24 \\
\hline \multicolumn{9}{|l|}{$\vdots$} \\
\hline Kazakhstan & 88 & 2,70 & 2,33 & 3,38 & 2,68 & 2,72 & 2,83 & 3,24 \\
\hline Sri Lanka & 89 & 2,70 & 2,56 & 2,23 & 2,56 & 2,91 & 2,76 & 3,12 \\
\hline Russia & 90 & 2,69 & 2,20 & 2,59 & 2,64 & 2,74 & 2,85 & 3,14 \\
\hline Uruguay & 91 & 2,68 & 2,39 & 2,51 & 2,64 & 2,58 & 2,89 & 3,06 \\
\hline
\end{tabular}

One of supply logistics efficiency indicators is the specific weight of logistic expenses in the company revenue. Possibility for comparison of the supply logistics capital costs including current costs and capital input brought to annual dimension is explained by the same revenue structure. The company revenue (B) can be presented as the sum of cost price (C) and the company assets brought to annual dimension $(A)$ on the basis of an indicator of their profitability (ROA):

\section{$\mathrm{B}=\mathrm{C}+\mathrm{ROA} A^{*} \mathrm{~A}$.}

The share of JSC AvtoVAZ supply logistics costs in the company revenue for the period from 2009 to 2014 is presented in table 3.

Table 3. Share of costs on inbound logistics in revenue

\begin{tabular}{|l|c|c|c|c|c|c|}
\hline Indicators & 2009 & 2010 & 2011 & 2012 & 2013 & 2014 (grade) \\
\hline Earnings, RUB bn. per year & 84,2 & 123,0 & 174,8 & 183,2 & 175,2 & 182,2 \\
\hline Common logistic costs, RUB bn. per year & 3,62 & 3,76 & 4,85 & 4,99 & 5,87 & 4,93 \\
\hline Share of common logistic costs in earnings, $\%$ & 4,3 & 3,1 & 2,8 & 2,7 & 3,4 & 2,7 \\
\hline
\end{tabular}

According to table 3 the smallest share of the company supply logistics costs in revenue $(2,7 \%)$ took place in 2012 and 2014, and the greatest $(4,3 \%)$ - in 2009.

The other method of the automobile company supply logistics efficiency assessment is definition of its integrated indicator including efficiency single-unit indicators. The indicators of supply logistics efficiency or its productivity are researched using the example of Fiat Auto supply chain in Brazil (Bronzo \& Oliveira, 2004). In particular, the importance of such indicators as interaction with limited number of suppliers, the primary use of motor transport in materials and components supply, the level of production stocks are paid attention to. In other studies (Bigliardi \& Bottani, 2014) such indicators of supply logistics efficiency as supplier' response time to orders, delivery reliability, cost price, costs for inventory and warehousing management, expenses on information technologies, a total cost of a supply chain are given. Some scientists developed conceptual models of supply chain efficiency measurement on the basis of the balanced system of indicators including material and non-material indicators (Barber, 2008). These indicators can be also used for an assessment of supply logistics efficiency. There are some studies where supply logistics efficiency indicators include indicators of an assessment and ranging of components suppliers in the frame of quality management system (Best Practices in Supplier Quality Management, 2014). In particular, these indicators refer to:

- level of component deficiency (PPM);

- number of the last quarter corrective actions; 
- production downtime due to the fault of a supplier;

- guarantee component reserves;

- $\quad$ supplier's relative rating.

The logistics efficiency assessment is sometimes suggested to be carried out according to KPI indicators (Key Performance Indicators) for different levels of company logistic management (Pilipenko, 2007).

The single-unit indicators of JSC AvtoVAZ supply logistics efficiency are presented in table 4.

Table 4. Single-unit indicators of JSC AvtoVAZ supply logistics efficiency

\begin{tabular}{|l|c|c|c|c|c|c|}
\hline Indicators & 2009 & 2010 & 2011 & 2012 & 2013 & 2014 \\
\hline Number of suppliers, thousand/unit. $\left(X_{1}\right)$ & 0,89 & 0,98 & 1,18 & 1,24 & 1,18 & 1,10 \\
\hline Number of stock items for one supplier, unit. $\left(X_{2}\right)$ & 36 & 36 & 31 & 33 & 40 & 41 \\
\hline Motor transportation share in delivery total volume, $\%\left(X_{3}\right)$ & 60,0 & 62,3 & 66,0 & 78,0 & 70,0 & 74,0 \\
\hline Level of delivery deficiency according to PPM, thousand/unit $\left(X_{4}\right)$ & 0,80 & 0,19 & 0,12 & 0,09 & 0,04 & 0,03 \\
\hline Productive supplies turnover, turnover per year $\left(X_{5}\right)$ & 4,92 & 11,01 & 11,49 & 11,87 & 9,96 & 10,52 \\
\hline
\end{tabular}

The choice of single-unit indicators of supply logistics efficiency was based on the qualitative analysis of the factors influencing a share of logistic expenses in revenue of the automobile company $(Y)$, and calculations of Pearson correlation coefficients. By assuming correlation coefficients $(r)$ of linear dependence between variables have the following values:

$r_{X_{1} Y}=0.852, \quad r_{X_{2} Y}=0.259, \quad r_{X_{3} Y}=0.697, \quad r_{X_{4} Y}=-0.730$,

$r_{X_{5} Y}=0.496$.

Low value of correlation coefficient between the number of the stock items for one supplier, and the share of logistic expenses in the automobile company revenue $(Y)$ is explained by their nonlinear.

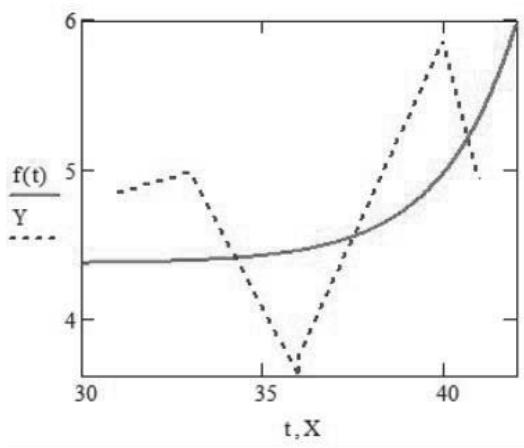

Figure 1. Nonlinear dependence between variables

The correlation coefficient for nonlinear dependence $f(t)$ between the number of the stock items for one supplier, and shares of logistic expenses in the automobile company revenue makes up 0,481 that testifies moderate degree of correlation between variables.

Single-unit indicators of supply logistics efficiency have different units of measure. Therefore their valuation in the range from 0 to 1 is carried out. Single-unit indicators valuation of supply logistics efficiency was carried out on the basis of the following assumptions:

- if the increase in value of single-unit indicators leads to decrease in a share of logistic expenses, their normalized variable is defined as the relation of each value to the maximum one;

- if the increase in value of single-unit indicators leads to the growth for a share of logistic expenses, their normalized variable is defined as the relation of the minimum value to all ones.

The normalized indicators of the automobile company supply logistics efficiency are presented in table 5. 
Table 5. Normalized values of single-unit indicators of JSC AvtoVAZ supply logistics efficiency

\begin{tabular}{|l|c|c|c|c|c|c|}
\hline Indicators & 2009 & 2010 & 2011 & 2012 & 2013 & 2014 \\
\hline Number of suppliers $\left(\mathrm{X}_{1}\right)$ & 1,000 & 0,908 & 0,754 & 0,718 & 0,754 & 0,809 \\
\hline Number of stock items for one supplier $\left(\mathrm{X}_{2}\right)$ & 0,878 & 0,878 & 0,756 & 0,805 & 0,976 & 1,000 \\
\hline Motor transportation share in delivery total volume $\left(\mathrm{X}_{3}\right)$ & 0,769 & 0,799 & 0,846 & 1,000 & 0,897 & 0,948 \\
\hline Level of delivery deficiency according to PPM $\left(\mathrm{X}_{4}\right)$ & 0,038 & 0,160 & 0,250 & 0,353 & 0,811 & 1,000 \\
\hline Productive supplies turnover $\left(\mathrm{X}_{5}\right)$ & 0,414 & 0,928 & 0,968 & 1,000 & 0,839 & 0,886 \\
\hline
\end{tabular}

Integrated indicator calculation of the automobile company supply logistics efficiency $(X)$ is based on the method, offered by Toymentseva I.A. in her work, as well as it is carried using the formula (Toymentseva, 2011):

$X=\sum_{i=1}^{5} \alpha_{i} \cdot X_{i}$,

where ai - weighting coefficients of normalized values of single-unit indicators.

Weighting coefficients or relative importance of efficiency single-unit indicators of supply logistics can be determined by expert or economic-mathematical methods. The simplest of expert methods is the experts' consensus of opinions on the relative importance of factors expressed as a percentage or unit shares (The Weighting and Scoring Method, 2014). As well as the method of paired comparisons (Klukowski, 2000), the method of construction and the analysis of a super-matrix (Huber et al., 2000), the universal method of the hierarchy analysis (Bakhtiyarov, 2010) are widely used. One of the current economic-mathematical methods of weighting coefficient determination is variation coefficient of factorial characteristic as random variables (Pavlova, 2013).

Weighting coefficients of single-unit indicators of supply logistics efficiency are calculated as the relation of integrated indicator dispersion $\left(\sigma_{X}^{2}\right)$ to dispersions of efficiency single-unit indicators $\left(\sigma_{X_{i}}^{2}\right)$ according to table 5 :

$$
\alpha_{i}=\frac{\sigma_{X}^{2}}{\sigma_{X_{i}}^{2}}
$$

Table 6. Integrated indicator calculation of JSC AvtoVAZ supply logistics efficiency

\begin{tabular}{|l|c|c|c|c|c|c|c|}
\hline Indicators & Bec & 2009 & 2010 & 2011 & 2012 & 2013 & 2014 \\
\hline Number of suppliers $\left(\mathrm{X}_{1}\right)$ & 0,238 & 1,000 & 0,908 & 0,754 & 0,718 & 0,754 & 0,809 \\
\hline Number of stock items for one supplier $\left(\mathrm{X}_{2}\right)$ & 0,320 & 0,878 & 0,878 & 0,756 & 0,805 & 0,976 & 1,000 \\
\hline Motor transportation share in delivery total volume $\left(\mathrm{X}_{3}\right)$ & 0,362 & 0,769 & 0,799 & 0,846 & 1,000 & 0,897 & 0,948 \\
\hline Level of delivery deficiency according to PPM $\left(\mathrm{X}_{4}\right)$ & 0,019 & 0,038 & 0,160 & 0,250 & 0,353 & 0,811 & 1,000 \\
\hline Productive supplies turnover $\left(\mathrm{X}_{5}\right)$ & 0,061 & 0,414 & 0,928 & 0,968 & 1,000 & 0,839 & 0,886 \\
\hline Integrated indicator & 1,000 & 0,823 & 0,846 & 0,791 & 0,858 & 0,883 & 0,929 \\
\hline
\end{tabular}

The highest efficiency of JSC AvtoVAZ supply logistics took place in 2014, the least one - in 2011.

\section{Discussion}

In this research a number of hypotheses is proposed, various methods of research are used and on their basis the results are received that can be under discussion.

Firstly, there are distinctions in assessments of the automobile company supply logistics efficiency according to the indicator of logistic expenses share in revenue and the integrated indicator. Therefore, the smallest share of logistic expenses in revenue $(2,8 \%)$ took place in 2012, and the highest value of an integrated indicator of supply logistics efficiency - in $2014(0,929)$. Secondly, there is a need and possibility for complementing the checklist of single-unit indicators of the automobile company supply logistics efficiency with such indicators as delivery average time, a number of local suppliers of material resources and a share of assembly module deliveries. Thirdly, the determination method of single-unit indicator weighting coefficients of supply logistics efficiency demands stricter scientific rationale. For example, weighting coefficients can be calculated according to extent of single-unit indicators change influence on the automobile company logistic expenses change.

\section{Conclusion}

The further research can be targeted at stating the purposes of the automobile company supply logistics efficiency enhancement, that is, growth for an efficiency integrated indicator, and as well as strategy development of logistic 
expenses minimization. In this regard, it is vital to develop a supply logistics target and strategy chart including targets and strategy of supply separate business processes management (purchases, transportation, outsourcing, maintenance of production stocks, warehousing).

\section{References}

25th Annual State of Logistics: It's complicated. Logistics Management. By John D. Schulz, Contributing Editor July 01, 2014. http://www.logisticsmgmt.com/article/25th_annual_state_of_logistics_its_complicated.

Boston Consulting Group, Committee on logistics of Chamber of Commerce and Industry of the Russian Federation. Logistics in Russia: new ways of potential fulfillment, April, 2014. Date of viewing November, 10, 2014. - http://www.bcg.ru/documents/file158550.pdf.

N.V. Makarova, Material resources management strategy formation [Text] / N. V. Makarova, L.A. Sosunova//Vestnik. Samara State University of Economics. - Samara, 2010. - No. 8. - pp. 71-75.

A. Szydechko, Costs of Logistics in the Company. The International Journal of TRANSPORT \& LOGISTICS, Issue 27/2013, Retrieved December 8, 2014, from http://www .sjf.tuke.sk/transportlogistics/wp-content/uploads/szydelko.pdf

J. Krajnc, K. Logožar, B. Korošec, Activity-Based Management of Logistic Costs in a Manufacturing Company: A Case of Increased Visibility of Logistic Costs in a Slovenian Paper Manufacturing Company. Promet - Traffic \& Transportation, Vol. 24, 2012, No. 1, $15-24 \mathrm{pp}$.

I. A. Mishchersky, Analysis of the general logistic expenses [Text] / I. A. Mishchersky//Young scientist. -2011 . - No. 6., Vol.1. pp.160-163.

L.B. Belov, Record and allocation of logistic expenses in control of purchase subsystem efficiency I/Loginfo, No. 2, 2001. Issue date: 22.08.2001. http://www .cfin.ru/press/loginfo/2001-02/03.shtml.

D.B. Lytvyna, Cost management efficiency in construction production on the basis of innovative logistics application. Electronic scientific journal "Don Engineering Bulletin ". No. 4 (part 2), 2012. Date of viewing December, 10, 2014. - http://www.ivdon.ru/ magazine/archive/n4p2y2012/1242.

O.S. Glinskaya., I.S. Skorikova, Classification of logistic expenses in retail companies//Audit and financial analysis, No. 2, 2011. Date of viewing December, 10, 2014. - http://www.auditfin.com/fin/2011/2/2011_II_02_04.pdf.

The World Bank. Logistics Performance Index. Retrieved November 10, 2014, from http://lpi.worldbank.org/international/global.

M. Bronzo, \& Paulo Valadares de Oliveira M. Logistical Organisation and Performance: Empirical Evidences from the Automotive Industry. 5. 12. 2014. http://www.cepead.face.ufmg.br/files/nucleos/nipe_log/Artigo5.pdf.

Bigliardi, B., Bottani, E. Supply chain performance measurement: a literature review and pilot study among Italian manufacturing companies. International Journal of Engineering, Science and Technology. Vol. 6, №. 3, 2014, pp. 1-16.

E. Barber, 2008, ' How to measure the value in value chains', International Journal of Physical Distribution and Logistics Management, vol. 38, no. 9, pp. 685 - 698, http://dx.doi.org/10.1108/09600030810925971.

Best Practices in Supplier Quality Management. Metric Stream. Retrieved December 6, 2014, from http://www.metricstream.com linsights/bestPractices_supgltymgmt.htm.

V. Pilipenko, Logistics efficiency assessment on the basis of KPI//HR Journal, No. 6, 2007. Date of viewing December, 10, 2014. http://www.hrm.ua/article/ocenka_jeffektivnosti_logistiki_na_osnove_KPI.

I.A. Toymentseva, Economic-mathematical services quality assessment methods of the motor transport [Text] / I.A. Toymentseva//TGU science Vector. - Tolyatti, 2011. - No. 4 (18). - pp. 331-336.

The Weighting and Scoring Method. Department of Finance and Personnel. Clare House 303 Airport Road. Belfast BT3 9ED. Retrieved December 8, 2014, from http://translate.google.ru/translate?hl=ru\&sl=en\&tl= ru\&u=http\%3A\%2F\%2Fwww.dfpni.gov.uk\%2Feagthe-weighting-and-scoring-method\&anno=2.

L. Klukowski, The nearest adjoining order method for pairwise comparisons in the form of difference of ranks. Annals of Operations Research. 12, 2000, Volume 97, Issue 1-4, pp. 357-378.

F. Huber, M. Fischer and A. Herrmann, (2000),"Supermatrix-Analysis as a Method of Measuring Interdependent Relative Importance Weights in Customer Satisfaction Research", in NA - Advances in Consumer Research Volume 27, eds.Stephen J. Hoch and Robert J. Meyer, Provo, UT : Association for Consumer Research, pp: 92-99.

R. S. Bakhtiyarov Revisited the role of investment management in regional economy//the Euroasian international scientific and analytical journal "Issues of Modern Economy", No. 2 (34), 2010. Date of viewing December, 11, 2014. - http://www.m-economy.ru lart.php?nArtld=3146.

K.S. Pavlova Influence of an auditor services quality assessment on customer satisfaction //Economic sciences, No. 5 (102), 2013. - pp. 100-103. Date of viewing December, 11, 2014. - http://ecsn.ru/files/pdf/201305.pdf. 